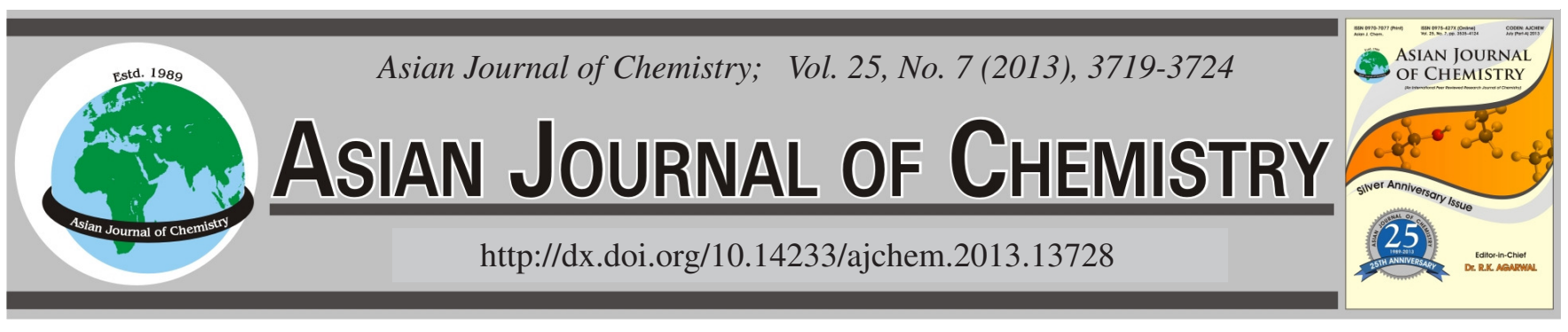

\title{
Micellar Electrokinetic Chromatographic Separation/Determination of Uranium, Iron, Copper and Nickel from Environmental Ore Samples Using Bis(salicylaldehyde)meso-stilbenediimine as Chelating Reagent
}

\author{
Muhammad Aslam Mirza, ${ }^{1, *}$, Muhammad Yar Khuhawar ${ }^{2}$, Rafee $_{\text {Arain }}{ }^{3}$, \\ Muhammad Aziz Choudhary ${ }^{1}$, Abdul Jabbar Kandhro ${ }^{5}$ and Taj Muhammad Jahangir ${ }^{6}$
}

\begin{abstract}
${ }^{1}$ Mirpur University of Science and Technology, Mirpur, Pakistan
${ }^{2}$ Institute of Advanced Research Studies in Chemical Sciences, University of Sindh, Jamshoro, Pakistan

*Corresponding author: E-mail: ma_mirza64@yahoo.com; aslamchem@must.edu.pk
\end{abstract}

\begin{abstract}
A micellar electrokinetic chromatographic (MEKC) method has been developed for the separation of U(VI), $\mathrm{Cu}(\mathrm{II}), \mathrm{Ni}(\mathrm{II}), \mathrm{Co}(\mathrm{II})$, $\mathrm{Co}(\mathrm{III}), \mathrm{Fe}(\mathrm{III}), \mathrm{Pd}(\mathrm{II})$ and determination of U(VI), Fe(III), Ni(II) and $\mathrm{Cu}(\mathrm{II})$ using bis(salicylaldehyde)meso-stilbenediimine (meso$\mathrm{H}_{2} \mathrm{SA}_{2} \mathrm{~S}$ ) as chelating reagent with a separation time $5 \mathrm{~min}$. Sodium dodecyl sulphate was used as micellar medium at $\mathrm{pH} 8.5$ with sodium tetraborate buffer $(0.1 \mathrm{M})$. Uncoated fused silica capillary with effective length $38.8 \mathrm{~cm} \times 75 \mu \mathrm{m}$ i.d was used with an applied voltage 25 $\mathrm{kV}$ with photo-diode array detection at $228 \mathrm{~nm}$. Linear calibrations were established within $0.03-1000 \mu \mathrm{g} / \mathrm{mL}$ of each element with detection limit within 10-260 ng/mL. The method was applied for the determination of uranium from ore samples in the range 104-1753 $\mu \mathrm{g} / \mathrm{g}$ with relative standard deviation (RSD) 1.0-2.1\%. Fe, Ni and $\mathrm{Cu}$ present in ore samples were also determined with RSD 0.6-2.7 \%. The results were compared with that of supplier's specifications and AAS. Method was validated by standard addition technique. The recovery of uranium from ore samples was calculated $98.6 \%$ with RSD $1.2 \%$.
\end{abstract}

Key Words: Micellar electrokinetic chromatography, Sodium dodecyl sulphate, Meso-stilbenediimine, Ore samples, Uranium.

\section{INTRODUCTION}

Uranium is well known for its use as nuclear fuel and is increasingly being used for power generation. The sensitive methods for determination of uranium are based on inductively coupled plasma mass spectrometry (ICP-MS) ${ }^{1,2}$, inductively coupled plasma atomic emission spectrometry (ICP-AES) ${ }^{3}$, $\mathrm{X}$-ray fluorescence spectrometry ${ }^{4}$, activation analysis ${ }^{5}$, high performance liquid chromatography (HPLC) ${ }^{6}$ and capillary electrophoresis $(\mathrm{CE})^{7-9}$. High sensitivity and selectivity for the determination of uranium is reported using HPLC with appropriate complexing reagents. For post-column derivatization complexing reagents commonly used are arsenazo III and 4-(2-pyridyl) resorcinol ${ }^{10-14}$. For pre-column derivatization, different hydrazones ${ }^{15,16}, \alpha$-hydroxyisobutyric $\operatorname{acid}^{17}$ and tetradentate Schiff bases ${ }^{18-21}$ have been reported.

The analytical procedures based on ICP-MS and ICP-AES are sensitive for multi-elemental analysis, but involve expensive equipment with high running cost.

Capillary electrophoresis (CE) is taking place for the analysis of metal ions due to its high resolution power, low solvent consumption and short analysis time ${ }^{22-28}$. Capillary electrophoresis separations are based on different modes including capillary zone electrophoresis (CZE) and micellar electrokinetic capillary chromatography (MEKC). The charged and neutral molecules are separated by MEKC based on solute partitioning between the micellar phase and the solution phase. Micelles are formed in solution, when a surfactant is added in concentration above its critical micelle concentration $(\mathrm{CMC})^{29}$. Capillary electrophoresis has been reported for the determination of U(VI) in the presence of metal ions using 4-(2thiazolazo) resorcinol ${ }^{30}, 2,6$-diacetylpyridine bis(N-methylenepyridenohydrazone $)^{31}, 2$-[(2-arsenophenyl)-azo]-1,8-dihydroxy7-[(2,4,6-tribromophenyl)-azo]-naphthelene-3,6-disulfonic $\operatorname{acid}^{32}$, arsenazo III ${ }^{33}, 2$-(2-arseno-phenylazo)-1,8-dihydroxyl7-(4-chloro-2,6-dibromophenyl azo)-naphthalene-3,6-disulfonic $\operatorname{acid}^{7}$, bis(salicylaldehyde) ethylenediimine $\left(\mathrm{H}_{2} \mathrm{SA}_{2} \mathrm{en}\right)^{8}$, bis(salicylaldehyde) propylenediimine $\left(\mathrm{H}_{2} \mathrm{SA}_{2} \mathrm{Pn}\right)^{9}$ and bis(acetylacetone) ethylenediimine.

Tetradentate Schiff base meso- $\mathrm{H}_{2} \mathrm{SA}_{2} \mathrm{~S}$ has been used as chelating reagent for the separation and determination of dioxouranium together with copper, nickel and iron with high performance liquid chromatography with UV detection ${ }^{21}$. The reagent meso $-\mathrm{H}_{2} \mathrm{SA}_{2} \mathrm{~S}$ contains two phenyl groups at bridge position as compared to the ligands $\mathrm{H}_{2} \mathrm{SA}_{2}$ en and $\mathrm{H}_{2} \mathrm{SA}_{2} \mathrm{Pn}$ (Fig. 1) and indicates higher sensitivity by UV detection ${ }^{21}$. 


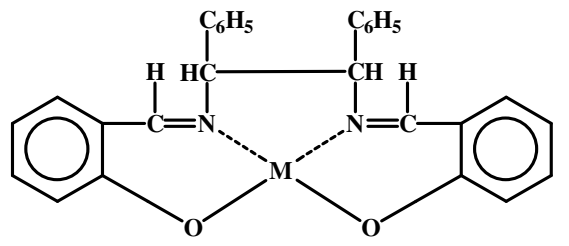

Fig. 1. Structural diagram of meso- $\mathrm{H}_{2} \mathrm{SA}_{2} \mathrm{~S}$ and its metal chelates

The work examines the same reagent (meso- $\mathrm{H}_{2} \mathrm{SA}_{2} \mathrm{~S}$ ) for the determination of uranium in the presence of copper, nickel and iron by MEKC from ore samples. The work focuses on the determination of uranium with short analysis time, low solvent consumption and large dynamic range for geological perspective as compared to HPLC.

\section{EXPERIMENTAL}

The reagent meso- $\mathrm{H}_{2} \mathrm{SA}_{2} \mathrm{~S}$ and its cobalt(II), cobalt(III), copper(II), nickel(II), iron(III), Pd(II) and dioxouranium(VI) complexes were prepared as reported ${ }^{21,34-37}$.

The chemicals and metal salts used were from Fluka (Switzerland), RDH (Germany), E-Merck (Germany) and BDH (Chemicals Ltd.UK). Meso-stilbenediamine was prepared as reported $^{38}$. The mineral ore samples (Sandstone house reference standards) were obtained from Atomic Energy Mineral Centre, Lahore, Pakistan.

Buffer solutions at unit interval between $\mathrm{pH} 1-6$, at 0.5 unit within 6-8 and 0.1 unit interval from 8 to 9 were prepared from solutions with a concentration $0.1 \mathrm{~mol} / \mathrm{L}$ from the following: hydrochloric acid-potassium chloride $\mathrm{pH}$ 1-2; acetic acid and sodium acetate $\mathrm{pH} 3-6$; ammonium acetate and acetic acid/ammonia solution pH 6.5 -8.0; boric acid and sodium tetraborate $\mathrm{pH} 8-9$; sodium bicarbonate and sodium carbonate $\mathrm{pH} 10$.

The $\mathrm{pH}$ measurements were made with an Orion 420A $\mathrm{pH}$ meter with combined glass electrode and reference internal electrode. The determination of copper, nickel and iron was carried out by Varian Spectr AA-20 atomic absorption spectrophotometer with standard burner head and air-acetylene flame at the conditions recommended by the manufacturer. Copper, nickel and iron were determined at 324.8, 232.0 and 248.3 $\mathrm{nm}$ in quadruplet $(\mathrm{n}=4)$ with integration time $3 \mathrm{~s}$ and delay time $3 \mathrm{~s}$.

The capillary electrophoresis (CE) system consists of Beckman Coulter P/ACE MDQ Instrument (Beckman Instruments Inc. Fullerton CA) equipped with an auto sampler, photo-diode array detector and a data system comprising of an IBM Personal computer and P/ACE system MDQ (32 karrat) software. Uncoated fused silica capillaries were obtained from (Beckman Instruments Inc's-CA) with total length $50 \mathrm{~cm}$, effective length $38.8 \mathrm{~cm}, 75 \mu \mathrm{m}$ id and $375 \mu \mathrm{m}$ od. The temperature of capillary and sample were maintained at $25^{\circ} \mathrm{C}$.

Prior to sample run, each day or at the time of observation of any distortion in the peak shape in electropherogram during the day, the capillary was regenerated and conditioned with methanol for $1 \mathrm{~min}$, followed by water for $0.5 \mathrm{~min}$, hydrochloric acid $(0.1 \mathrm{M})$ for $2 \mathrm{~min}$, water for $0.5 \mathrm{~min}$, sodium hydroxide $(0.1 \mathrm{M})$ for $2 \mathrm{~min}$, water for $0.5 \mathrm{~min}$ and finally running buffer for 2 min At the time of frequent fall of current, sodium dodecyl sulphate (SDS) medium was replaced with simple borate buffer to stabilize the current and then again SDS medium was established. Reverse washing was also carried out to regenerate the capillary. Before and after each sample injection the capillary was washed with sodium hydroxide $(0.1$ M) for $2 \mathrm{~min}$, water for $1.0 \mathrm{~min}$ and then equilibrated with the running buffer for $2 \mathrm{~min}$. The sample was injected by an auto sampler with pressure of 0.5 Psi for $4 \mathrm{~s}$. The electrophoretic migration was optimized with boric acid-sodium tetraborate $(0.1 \mathrm{M})$ : SDS $(0.03 \mathrm{M})(2: 1 \mathrm{v} / \mathrm{v})$ with an applied voltage of 25 $\mathrm{kV}$. Photodiode array detection was at $228 \mathrm{~nm}$.

Analytical procedure: Aqueous solution $(3 \mathrm{~mL})$ containing uranium(VI) $(0.03-1000 \mu \mathrm{g} / \mathrm{mL})$, iron(III) $(0.042-1000 \mu \mathrm{g} /$ $\mathrm{mL})$, nickel(II) $(0.09-125 \mu \mathrm{g} / \mathrm{mL})$, copper(II) $(0.09-125 \mu \mathrm{g} /$ $\mathrm{mL})$, cobalt(II) $(0.12-250 \mu \mathrm{g} / \mathrm{mL})$, cobalt(III) $(0.045-250 \mu \mathrm{g} /$ $\mathrm{mL})$, palladium(II) $(0.78-1000 \mu \mathrm{g} / \mathrm{mL})$ was transferred to screw capped sample vials and was added acetic acid-sodium acetate buffer pH $6(2 \mathrm{~mL})$. The reagent (meso- $\left.\mathrm{H}_{2} \mathrm{SA}_{2} \mathrm{~S}\right)$ solution $(2 \mathrm{~mL}, 1 \% \mathrm{w} / \mathrm{v}$ in methanol) was then added and contents were warmed on water bath at $70{ }^{\circ} \mathrm{C}$ for $10 \mathrm{~min}$. After cooling at room temperature, chloroform $(3 \mathrm{~mL})$ was added and the contents were allowed to mix well. The layers were separated and the organic layer $2 \mathrm{~mL}$ was drawn out and evaporated under nitrogen atmosphere. The residue was dissolved in solvent system $(2 \mathrm{~mL})$ comprising methanol: acetonitrile: water (40:40:20 v/v/v). The solution placed in septum capped vial was injected by auto sampler and electropherograms recorded at the optimized conditions.

Analysis of uranium, iron, copper and nickel in mineral ore samples: Ore sample $(0.3 \mathrm{~g})$ each from 38834,38835 , 38842,38849 and 38850 was transferred to beaker and was added hydrochloric acid (37\%) (15 mL) and nitric acid $(65 \%)$ $(5 \mathrm{~mL})$. The contents were heated gently on a hot plate and when most of the acid had evaporated, the nitric acid $(65 \%)$ $(5 \mathrm{~mL})$ was added. The contents were again heated to near dryness and the residue was dissolved in nitric acid $0.1 \mathrm{~N}$. The solution was filtered and volume adjusted to $25 \mathrm{~mL}$. The solution (1-3 mL) was taken and "Analytical Procedure" was followed. The quantitation was carried out with the external calibration curve derived for standard solution of each element.

Uranium assay by standard addition method: To standard sample number $38834(0.3 \mathrm{~g})$ was added $50 \mu \mathrm{g}$ of uranium and "Analytical Procedure" was followed. The quantitation was carried out using linear calibration curve and from an increase in the response with added uranium.

\section{RESULTS AND DISCUSSION}

The reagent reacts and forms neutral metal chelate with dioxouranium(VI), readily extractable in chloroform, ethyl acetate and methyl isobutyl ketone (MIBK). The maximum transfer of the metal chelate from aqueous to organic phase occurred within $\mathrm{pH}$ 4-9 with maximum in neutral solution. In acidic solution the protonation of the ligand and in basic solution hydroxyl formation of the metal ions retarded the complexation and solvent extraction, but for the extraction of uranium in the presence of iron(III), copper(II) and nickel(II), 
pH 6 was selected to prevent iron(III) oxide formation in neutral solution as reported earlier ${ }^{17}$.

Optimization of capillary electrophoresis conditions: The electrophoretic mobility of dioxouranium(VI) complex in the presence of surfactant tetrabutyl ammonium bromide, Tween 40 and SDS at CMC was examined in sodium acetate, ammonium acetate, sodium tetraborate and sodium carbonate buffers within $\mathrm{pH}$ 3-9. A significant increase in electrophoretic mobility and an improvement in the peak shape were observed with a complete separation of uranyl complex from derivatizing reagent using SDS and sodium tetraborate buffer as has been observed for related derivatizing reagents ${ }^{8,9,39}$.

Effect of pH: The effect of $\mathrm{pH}$ within 3-9 in the presence of SDS in the buffer system on the electrophoretic mobility of metal chelates (1) $\mathrm{Co}(\mathrm{III}),(2) \mathrm{Co}(\mathrm{II})$, (3) reagent $\mathrm{H}_{2} \mathrm{SA}_{2}$ en, (4) $\mathrm{Ni}(\mathrm{II}),(5) \mathrm{Cu}(\mathrm{II}),(6) \mathrm{UO}_{2}$ (II), (7) $\mathrm{Fe}$ (III) and (8) $\mathrm{Pd}(\mathrm{II})$ was examined (Fig. 2). The electrophoretic mobilities were calculated as reported ${ }^{9}$. The electrophoretic mobility was not observed for the metal chelates and chelating reagent within $\mathrm{pH}$ 3.0-6.5, but an electrophoretic mobility was indicated within $\mathrm{pH}$ 6.5-9.0. At $\mathrm{pH} 6.5$ and 7.0 all the metal chelates eluted as single peak. $\mathrm{pH} 7.5$ indicated three peaks where (1) corresponded to $\mathrm{Co}$ (III) and $\mathrm{Co}(\mathrm{II}),(2) \mathrm{Ni}(\mathrm{II})$ and (3) $\mathrm{Cu}$ (II), $\mathrm{U}(\mathrm{VI}), \mathrm{Fe}(\mathrm{III})$ and $\mathrm{Pd}(\mathrm{II})$. At pH 8 all the metal chelates separated, but at $\mathrm{pH} 8.5$ a better separation was observed. Again further increase in $\mathrm{pH}$ resulted in the decrease in the separation and at $\mathrm{pH} 9$ little separation was observed (Fig. 2). It was therefore $\mathrm{pH} 8.5$ using borate buffer was used throughout in the study. Cobalt(III) eluted before cobalt(II), because $\mathrm{Co}$ (III) is a charged species as compared to $\mathrm{Co}$ (II) due to the complexation of the ligand $\mathrm{H}_{2} \mathrm{SA}_{2} \mathrm{en}$ as diaminic tetradentate chelating reagent. The metal chelates once formed were highly stable and did not show any change in response (migration time and peak height) when injected after different time intervals upto $24 \mathrm{~h}$. As a control test, the separation was also examined without the addition of SDS. The metal chelates eluted as distorted peaks without any reasonable separation.

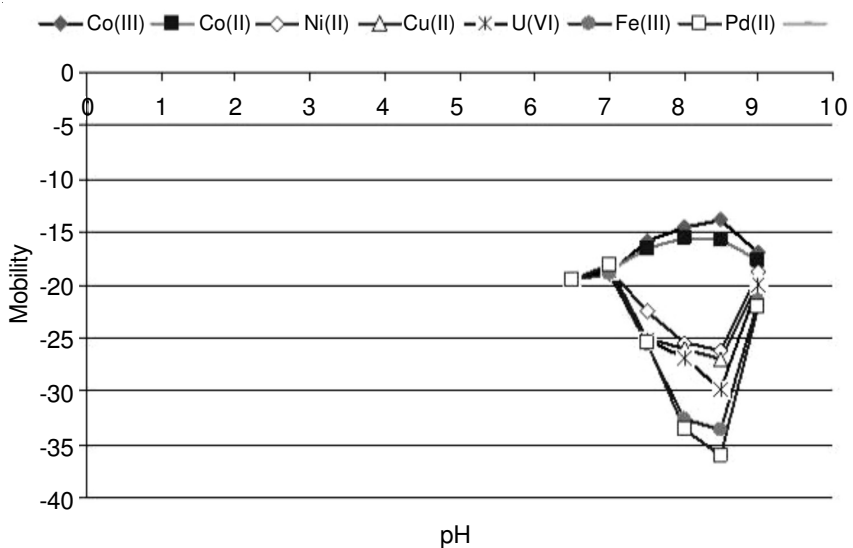

Fig. 2. Effect of $\mathrm{pH}$ on $\mu_{\mathrm{ep}}$ of metal chelates on uncoated silica capillary with total length $50 \mathrm{~cm}$ and effective length $38.8 \mathrm{~cm}$ with $75 \mu \mathrm{m}$ id at $25{ }^{\circ} \mathrm{C}$. Run buffer tetraborate $(0.1 \mathrm{M}), \operatorname{SDS}(0.03 \mathrm{M})(2: 1 \mathrm{v} / \mathrm{v})$, voltage $25 \mathrm{kV}$ and photodiode array detection at $228 \mathrm{~nm}$

Effect of buffer and sodium dodecyl sulphate concentration: The ratio of borate buffer $(0.1 \mathrm{M})$ at $\mathrm{pH} 8.5$ and SDS $(0.03 \mathrm{M})$ was varied from 1:1-4:1 v/v. Maximum separation was obtained with buffer:SDS (2:1v/v) and was selected. The concentration of borate buffer and SDS were varied from 0.01$0.21 \mathrm{M}$ (at 0.02 unit interval) and 0.01-0.07 M (at 0.01 unit interval) respectively at $\mathrm{pH} 8.5$, keeping buffer:SDS $(2: 1 \mathrm{v} / \mathrm{v})$. Better peak shape with complete separation was again observed using $0.1 \mathrm{M}$ borate buffer and 0.03 M SDS in 2:1 with resolution factor (Rs) between adjacent peaks $>1.5$ (Fig. 3). The identification of the peaks was based on migration time determination for each metal chelate separately and confirmed by spiking each metal ion in sequence in a mixture.

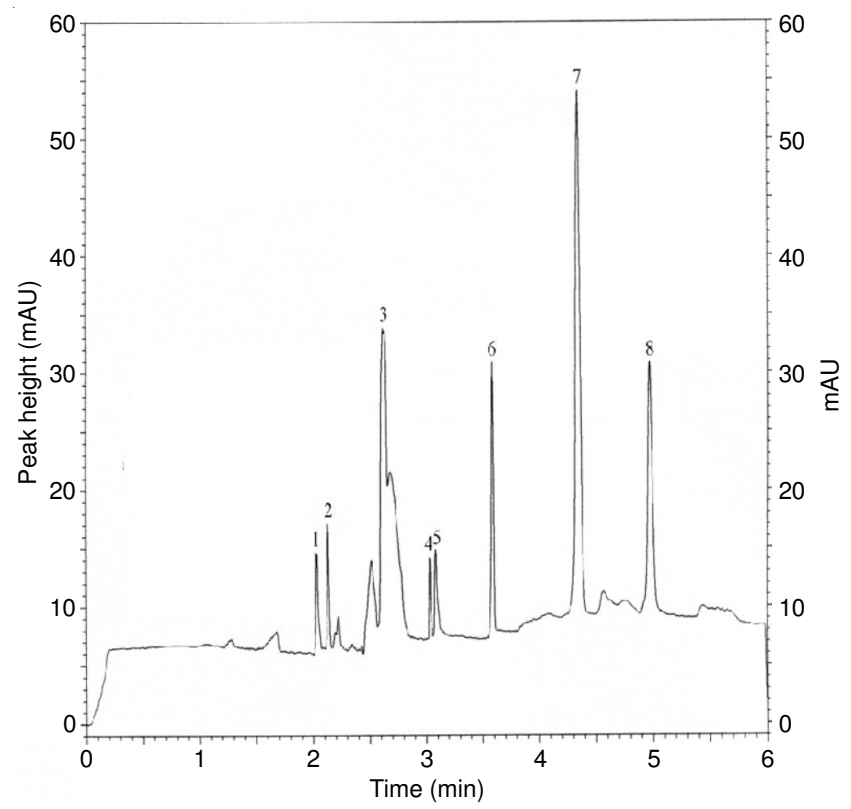

Fig. 3. MEKC separation of (1) $\mathrm{Co}(\mathrm{III})$, (2) $\mathrm{Co}(\mathrm{II})$, (3) $m e s o-\mathrm{H}_{2} \mathrm{SA}_{2} \mathrm{~S}$, (4) $\mathrm{Ni}(\mathrm{II}),(5) \mathrm{Cu}(\mathrm{II}),(6) \mathrm{UO}_{2}$ (II), (7) $\mathrm{Fe}$ (III) and (8) $\mathrm{Pd}(\mathrm{II})$ as derivatives of meso- $\mathrm{H}_{2} \mathrm{SA}_{2} \mathrm{~S}$. Conditions as Fig. 2

Effect of voltage: The applied voltage was varied from $15-30 \mathrm{kV}$ at an interval of $2 \mathrm{kV}$, as voltage increased the migration time decreased. At high applied voltage $(25 \mathrm{kV})$, a decrease in the separation time was observed, with an acceptable separation between seven metal chelates and complexing reagent within $5 \mathrm{~min}$.

Effect of solvent for metal chelates: The metal chelates of $m e s o-\mathrm{H}_{2} \mathrm{SA}_{2} \mathrm{~S}$ are less soluble in water and are more soluble in organic solvents. When the solution of metal chelates in methanol or acetonitrile was used, a fall in the current was observed. For better solubility of metal chelates and still maintaining the current, different mixtures of methanol-acetonitrile-water comprising (40:40:20 v/v/v), (35:35:30 v/v/v) and $(45: 45: 10 \mathrm{v} / \mathrm{v} / \mathrm{v})$ were examined. The solvent system methanol: acetonitrile: water (40:40:20 v/v/v) gave more reproducible results and was selected.

Selection of wavelength: The metal chelates absorb within visible region due to $d$ - $d$ or charge transfer transition but for better sensitivity the wavelength of maximum absorbance was scanned between 200-300 nm using photodiode array detection. A maximum response of the metal chelates examined was observed at $228 \mathrm{~nm}$ due to $\pi-\pi *$ transition in benzenoid ring systems and was used.

Validation and quantitation: Linear calibration curves were drawn by recording average peak height/peak area 
$(\mathrm{n}=5)$ versus concentration at the selected operating conditions. The calibrations were linear between $0.03-1000 \mu \mathrm{g} / \mathrm{mL}$. Coefficient of determination $\left(\mathrm{R}^{2}\right)$ with 15 calibrators was within 0.9981-0.9993. The results of quantitative data including regression equations, limit of detection (LOD) and limit of quantitation are summarized in Table-1. LOD measured as signal to noise ratio (3:1) were obtained within 10-260 ng/mL with lowest for uranium, iron(III), cobalt(III) and highest for palladium(II). LOQs measured as signal to noise ratio $(\mathrm{S} / \mathrm{N})$ (10:1) were obtained within 30-780 ng/mL (Table-1). Standard deviation, confidence internal at $95 \%$ and $\%$ error for slope (b) and intercept (a) of the linear calibration curves obtained on the basis of least square method for $\mathrm{UO}_{2}(\mathrm{II}), \mathrm{Fe}(\mathrm{III}), \mathrm{Ni}$ (II) and $\mathrm{Cu}(\mathrm{II})$ are summarized in Table-2. The error from calibration was calculated within $0.98-3.98 \%$. Repeatability precision in terms of migration time and peak height was examined for the 6 metal chelates of U, Fe, Ni, Cu, Co and Pd (10-250 $\mu \mathrm{g} /$ $\mathrm{mL})$ for inter-day $(\mathrm{n}=5)$ and intra-day $(\mathrm{n}=5)$ variations. The variations in peak heights inter and intraday were observed with RSD 2.0-3.1 and 1.5-2.9\% and in migration time were 1.3-1.7 and 0.9-1.4\%, respectively. The analysis of four test mixtures of aqueous solutions of U(IV), Fe(III), Ni(II) and $\mathrm{Cu}(\mathrm{II})$ within the calibration range of each element indicated relative error within $\pm 4 \%$.

Interference in uranium determination: $\mathrm{Fe}(\mathrm{III}), \mathrm{Ni}(\mathrm{II})$, $\mathrm{Cu}(\mathrm{II}), \mathrm{Co}(\mathrm{II})$ and $\mathrm{Co}(\mathrm{III}), \mathrm{Pd}(\mathrm{II})$, when present together with $\mathrm{UO}_{2}$ (II) as the metal chelates of meso- $\mathrm{H}_{2} \mathrm{SA}_{2} \mathrm{~S}$, separated completely without affecting the determination of $\mathrm{UO}_{2}$ (II) with relative \% error within $2.2-3.2 \%$. $\mathrm{Mn}$ (II) and $\mathrm{Zn}$ (II) when added in concentration as that of $\mathrm{UO}_{2}$ (II) did not interfere. Presence of $\mathrm{Al}(\mathrm{III})$ however decreased the $\%$ extraction of uranium, but when it was masked with $(1 \mathrm{~mL}, 1 \%) \mathrm{NH}_{4} \mathrm{~F}$ relative error lay within $\pm 1.9 \%$.

Analysis of uranium ore samples: Five uranium ore samples (sandstone house reference standards) obtained from Atomic Energy Mineral Centre Lahore, Pakistan were analyzed after acid digestion. The amount of uranium found were within $104-1753 \mu \mathrm{g} / \mathrm{g}$ with RSD 1.0-2.7 \%.The values agreed with reported values of $106-1718 \mu \mathrm{g} / \mathrm{g}$ by the supplier (Table-3).
Student's $t$-test was applied and no significant difference was indicated at $95 \%$ confidence level. A standard sample (38834) was spiked with $50 \mu \mathrm{g}$ of uranium and analysis was carried out by "Analytical Procedure", the recovery of uranium extracted was found to be $98.6 \%$ with RSD $1.2 \%$ (Figs. 4 and 5).

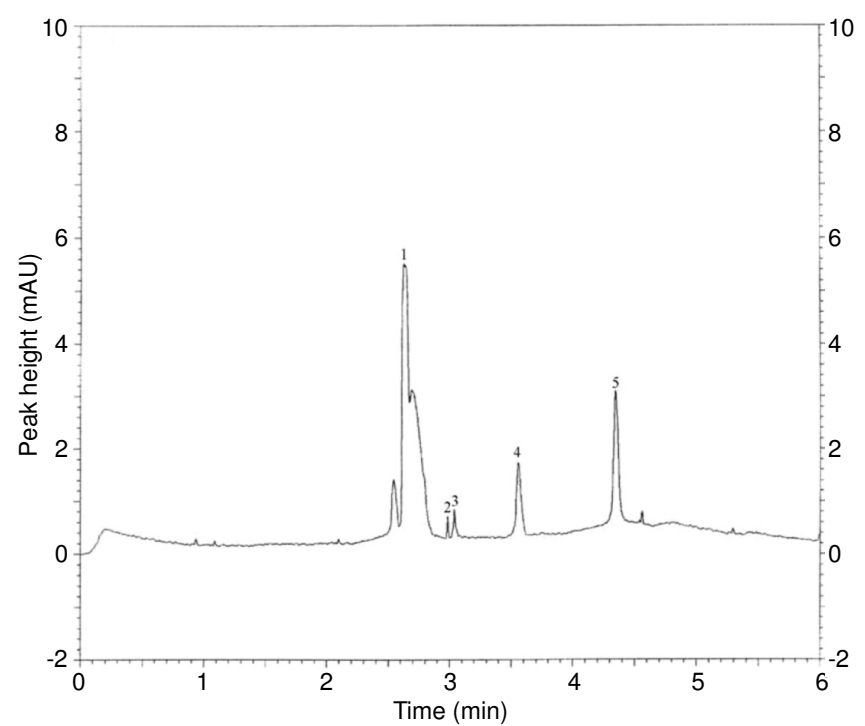

Fig. 4. Analysis of ore sample (1) meso- $\mathrm{H}_{2} \mathrm{SA}_{2} \mathrm{~S}$, (2) Ni(II), (3) $\mathrm{Cu}(\mathrm{II})$, (4) $\mathrm{UO}_{2}(\mathrm{II})$ and (5) $\mathrm{Fe}(\mathrm{III})$ as chelates of meso- $\mathrm{H}_{2} \mathrm{SA}_{2} \mathrm{~S}$. Conditions as Fig. 2

The ore samples also indicated $\mathrm{Fe}, \mathrm{Cu}$ and $\mathrm{Ni}$ presence hence their amounts in the samples were also determined. The amounts of $\mathrm{Fe}, \mathrm{Ni}$ and $\mathrm{Cu}$ were found within 10801-62195, 41.5-53.2 and 21.1-46.7 $\mu \mathrm{g} / \mathrm{g}$ with RSD 0.6-1.7, 0.9-1.8 and $0.7-2.7 \%$ respectively. The results were confirmed by the analysis of samples for copper, iron and nickel by air acetylene flame AAS. A close correlation between the results of micellar electrokinetic chromatographic (MEKC) and AAS was obtained. A paired $t$-test was applied for the comparison of the mean and no significant difference at $95 \%$ confidence level was indicated (Table-3).

\begin{tabular}{|c|c|c|c|c|c|}
\hline \multicolumn{6}{|c|}{$\begin{array}{c}\text { TABLE- } 1 \\
\text { QUANTITATIVE DATA OF METAL CHELATES OF MESO-H }{ }_{2} \mathrm{~S}\end{array}$} \\
\hline Metal & $\begin{array}{l}\text { Calibration range } \\
(\mu \mathrm{g} / \mathrm{mL})\end{array}$ & $\begin{array}{l}\text { Limit of quantitiation } \\
\text { (LOQ) }(\mu \mathrm{g} / \mathrm{mL})\end{array}$ & $\begin{array}{l}\text { Limit of detection } \\
(\mathrm{LOD})(\mu \mathrm{g} / \mathrm{mL})\end{array}$ & $\begin{array}{c}\text { Coefficient of } \\
\text { determination }\left(\mathrm{R}^{2}\right)\end{array}$ & $\begin{array}{l}\text { Electrophoretic mobilities } \\
\left(\mu_{\mathrm{ep}}\right)\left(\mathrm{cm}^{2} / \mathrm{kV} \text { min }\right)\end{array}$ \\
\hline Uranium(VI) & $0.030-1000$ & 0.030 & 0.010 & 0.9993 & -29.85 \\
\hline Iron(III) & $0.042-1000$ & 0.042 & 0.014 & 0.9988 & -33.71 \\
\hline Nickel(II) & $0.090-125$ & 0.090 & 0.030 & 0.9986 & -26.15 \\
\hline Copper(II) & $0.090-125$ & 0.090 & 0.030 & 0.9984 & -26.99 \\
\hline Cobalt(III) & $0.045-250$ & 0.045 & 0.015 & 0.9986 & -13.91 \\
\hline Palladium(II) & $0.780-1000$ & 0.780 & 0.260 & 0.9987 & -36.05 \\
\hline
\end{tabular}

TABLE-2

STATISTICAL DATA FOR THE ANALYSIS OF U(VI), Fe(III), Ni(II) AND Cu(II) BY MEKC

\begin{tabular}{llcccccc}
\multicolumn{1}{c}{ Metal } & \multicolumn{1}{c}{ Regression equation } & Sb & 95 \% CL b & Error (\%) & Sa & 95 \% CL a & Error (\%) \\
\hline Uranium(VI) & $\mathrm{y}=246.81 \mathrm{x}+1469.1$ & 1.899 & \pm 4.29 & 1.74 & 8.950 & \pm 20.24 & 1.38 \\
Iron(III) & $\mathrm{y}=32.813 \mathrm{x}+33.24$ & 0.580 & \pm 1.31 & 3.99 & 0.487 & \pm 1.102 & 3.32 \\
Nickel(II) & $\mathrm{y}=340.08 \mathrm{x}+356.42$ & 1.477 & \pm 3.34 & 0.98 & 1.820 & \pm 4.120 & 1.16 \\
Copper(II) & $\mathrm{y}=347.7 \mathrm{x}+231.15$ & 1.654 & \pm 3.74 & 1.07 & 1.312 & \pm 2.970 & 1.28 \\
\hline
\end{tabular}

$\mathrm{CL} \mathrm{b}=$ Confidence limits for slope $\mathrm{b}$. $\mathrm{CL} \mathrm{a}=$ Confidence limits for intercept $\mathrm{a}$. Sb = standard deviation of slope $\mathrm{b}$. Sa = standard deviation of intercept a. 


\begin{tabular}{|c|c|c|c|c|c|}
\hline \multicolumn{6}{|c|}{ 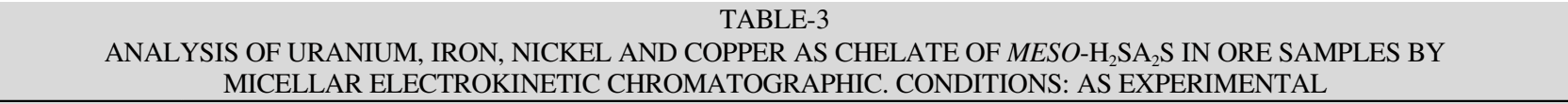 } \\
\hline Sample No. & Metal ion & $\begin{array}{l}\text { Amount found by CE, } \\
(\mu \mathrm{g} / \mathrm{g})(\mathrm{RSD} \%)\end{array}$ & $\begin{array}{c}\text { Amount found by AAS, } \\
(\mu \mathrm{g} / \mathrm{g})(\mathrm{RSD} \%)\end{array}$ & $\begin{array}{l}\text { Amount of uranium reported by } \\
\text { supplier }(\mu \mathrm{g} / \mathrm{g})\end{array}$ & $\begin{array}{c}\text { Relative } \\
\text { deviation }(\%)\end{array}$ \\
\hline \multirow{5}{*}{ *38834 } & $\mathrm{U}$ & $104(1.75)$ & - & 106.0 & 1.89 \\
\hline & & $104.5(1.23)$ & - & - & - \\
\hline & $\mathrm{Fe}$ & 10801 (1.7) & $10620(2.8)$ & - & - \\
\hline & $\mathrm{Ni}$ & $38.5(0.9)$ & $42.0(1.8)$ & - & - \\
\hline & $\mathrm{Cu}$ & $37.4(0.7)$ & $38.0(0.8)$ & - & - \\
\hline \multirow{4}{*}{38835} & $\mathrm{U}$ & 637.5 (1.47) & - & 626.6 & 1.74 \\
\hline & $\mathrm{Fe}$ & $17193(0.6)$ & $16870(0.8)$ & - & - \\
\hline & $\mathrm{Ni}$ & $53.2(1.1)$ & $52.0(1.3)$ & - & - \\
\hline & $\mathrm{Cu}$ & $27.8(1.9)$ & $26.0(2.5)$ & - & - \\
\hline \multirow{4}{*}{38842} & $\mathrm{U}$ & $439.6(1.32)$ & - & 423.0 & 3.92 \\
\hline & $\mathrm{Fe}$ & $62195(1.2)$ & $60620(0.6)$ & - & - \\
\hline & $\mathrm{Ni}$ & $47.1(1.3)$ & $48.6(1.6)$ & - & - \\
\hline & $\mathrm{Cu}$ & $46.7(0.9)$ & $48.0(1.1)$ & - & - \\
\hline \multirow{4}{*}{38849} & $\mathrm{U}$ & $1250.7(2.1)$ & - & 1273.7 & 1.8 \\
\hline & $\mathrm{Fe}$ & $21013(1.3)$ & $18120(1.1)$ & - & - \\
\hline & $\mathrm{Ni}$ & $44.0(1.7)$ & $48.0(2.1)$ & - & - \\
\hline & $\mathrm{Cu}$ & $34.1(1.2)$ & $36.0(1.4)$ & - & - \\
\hline \multirow{4}{*}{38850} & $\mathrm{U}$ & $1753(1.03)$ & - & 1718.0 & 2.04 \\
\hline & $\mathrm{Fe}$ & 51395 (1.7) & 49370 (1.8) & - & - \\
\hline & $\mathrm{Ni}$ & $41.5(1.8)$ & $46.0(2.8)$ & - & - \\
\hline & $\mathrm{Cu}$ & $21.1(2.1)$ & $23.0(3.6)$ & - & - \\
\hline
\end{tabular}

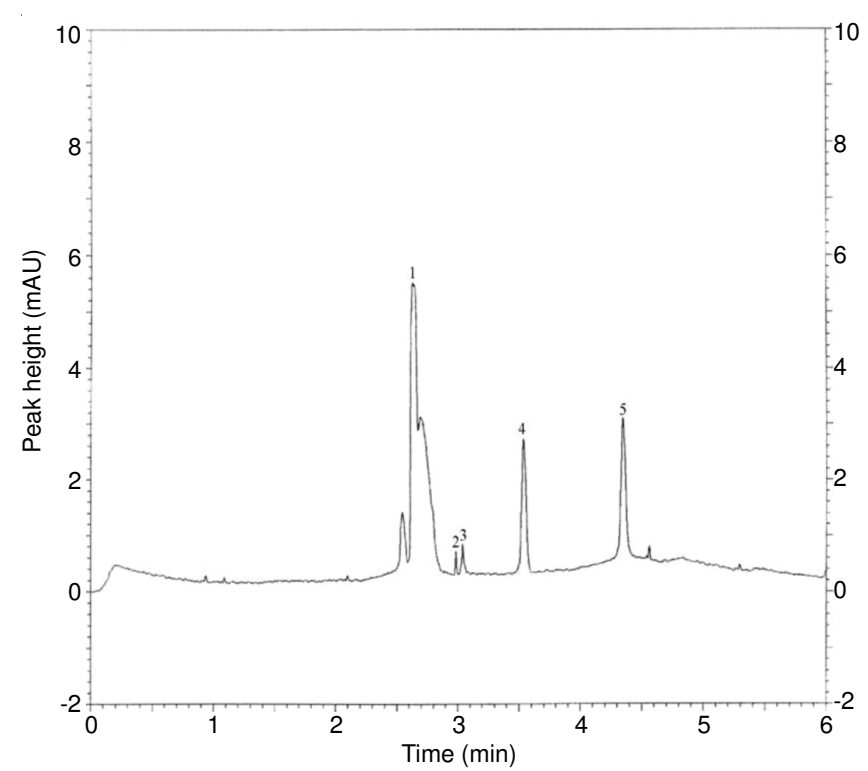

Fig. 5. Analysis of ore sample by standard addition (1) meso- $\mathrm{H}_{2} \mathrm{SA}_{2} \mathrm{~S}$, (2) $\mathrm{Ni}(\mathrm{II}),(3) \mathrm{Cu}(\mathrm{II}),(4) \mathrm{UO}_{2}(\mathrm{II})$, and (5) $\mathrm{Fe}(\mathrm{III})$ as chelates of meso$\mathrm{H}_{2} \mathrm{SA}_{2} \mathrm{~S}$. Conditions as Fig. 2

Comparing the results of MEKC with reported HPLC procedure ${ }^{17}$ using the same complexing reagent meso- $\mathrm{H}_{2} \mathrm{SA}_{2} \mathrm{~S}$, MEKC indicates short analysis time $(5 \mathrm{~min}$ ) for the separation of seven metal chelates as compared to 14 min by HPLC for the separation of 5 metal chelates. HPLC procedure involved the elution with methanol:acetonitrile:water (40:30:30 $\mathrm{v} / \mathrm{v} / \mathrm{v}$ ) with a flow rate $1.0 \mathrm{~mL}$, requiring $14 \mathrm{~mL}$ for each elution but MEKC required borate buffer $(0.1 \mathrm{M})$ and $\operatorname{SDS}(0.03 \mathrm{M})$ mixed in ratio $2: 1 \mathrm{v} / \mathrm{v}$ with solvent consumption $<0.2 \mathrm{~mL}$ per analysis. The dynamic range observed with $0.03-1000 \mu \mathrm{g} / \mathrm{mL}$ of metal ions using MEKC is also broader than HPLC. Low run cost of the equipment with short analysis time is the added advantage of MEKC for the analysis of $\mathrm{U}, \mathrm{Fe}, \mathrm{Cu}$ and $\mathrm{Ni}$ from geological materials.

Now comparing the lower limits of detection (LOD's) with reported MEKC method ${ }^{8}$ using $\mathrm{H}_{2} \mathrm{SA}_{2}$ en as complexing reagent, an improvement of LOD's was observed 20-67 \% for $\mathrm{Fe}(\mathrm{III}), \mathrm{Ni}(\mathrm{II}), \mathrm{Cu}(\mathrm{II}), \mathrm{Co}(\mathrm{II}), \mathrm{Co}(\mathrm{III}), \mathrm{Pd}(\mathrm{II})$ and $87 \%$ for $\mathrm{UO}_{2}$ (II) due to the addition of two phenyl groups in $\mathrm{H}_{2} \mathrm{SA}_{2}$ en ligand at bridge position to form meso- $\mathrm{H}_{2} \mathrm{SA}_{2} \mathrm{~S}$. MEKC elution of meso- $\mathrm{H}_{2} \mathrm{SA}_{2} \mathrm{~S}$ was observed after $\mathrm{Co}$ (III) and $\mathrm{Co}$ (II), as compared to $\mathrm{H}_{2} \mathrm{SA}_{2}$ en, where $\mathrm{H}_{2} \mathrm{SA}_{2}$ en eluted before metal chelates ${ }^{8}$.

\section{Coclusion}

An MEKC method has been developed for the determination of uranium in a combined matrix of copper, nickel and iron with separation time $5 \mathrm{~min}$ by its chelation with meso$\mathrm{H}_{2} \mathrm{SA}_{2} \mathrm{~S}$. Cobalt and palladium could also be determined if present together. Reproducible results were obtained with RSD within $2.7 \%$ for migration time and peak height. The recovery of U(VI) from samples was calculated $98.6 \%$. The results of MEKC method are comparable to the supplier's specification and its recheck on AAS. Use of simple buffer solution for electrophoretic mobility and low solvent consumption are added advantages of the MEKC method.

\section{REFERENCES}

1. K. Benkhedda, V.N. Epov and R.D. Evans, J. Anal. Bioanal. Chem., 38, 1596 (2005).

2. J. Fietzke, V. Liebetran, A. Eisenhaver and C.H. Dullo, J. Anal. At. Spectr., 20, 395 (2005).

3. M.R. Jamali, Y. Assadi, F. Shemirani, M.R.M. Hosseini, R.R. Kozani, M. Masteri Farahani and M. Salavati-Niasari, Anal. Chim. Acta., 579, 68 (2006).

4. A.P. Krinitsyn, O.L. Strikhar, A.V. Terletskaya and T.A. Bogoslovskaya, Radiochemistry, 47, 209 (2005).

5. L. Zikovsky, J. Radioanal. Nucl. Chem., 267, 695 (2006). 
6. N.M. Rout, P.G. Jason and S.K. Aggarwal, J. Chromatogr. A, 1052, 131 (2004).

7. B. Liu, L. Liu and J. Cheng, Talanta, 47, 291 (1998).

8. M.A. Mirza, M.Y. Khuhawar and R. Arain, Electrophoresis, 29, 597 (2008).

9. M.A. Mirza, M.Y. Khuhawar and R. Arain, J. Sep. Sci., 31, 3037 (2008).

10. D.J. Barkely, M. Blanchette, R.M. Cassidy and S. Elchuk, Anal. Chem., 58, $2222(1986)$

11. I. Jacaroua, H. Krizova and V. Kuban, Talanta, 38, 1093 (1991).

12. M.P. Harrold, A. Ciriraks and J.M. Riviello, J. Chromatogr. A, 602, 119 (1992)

13. C.A. Lucy, L. Gureli and S. Eluchuk, Anal. Chem., 65, 3320 (1993).

14. M.J. Shaw, S.J. Hill, P. Jones and N.L. Newterenks, Chromatographia 551, 695 (2000).

15. A. Casoli, A. Mangia and G. Predieri, Anal. Chem., 57, 561 (1983).

16. M.V. Main and J.S. Fritz, Anal. Chem., 16, 1272 (1989).

17. H. Fuping, P.R. Haddad, P.E. Jackson and J. Carne Vale, J. Chromatogr. A, 640, 187 (1983)

18. M.Y. Khuhawar and S.N. Lanjwani, Talanta, 42, 1925 (1995).

19. M.Y. Khuhawar and S.N. Lanjwani, J. Chromatogr. A, 740, 296 (1996).

20. M.Y. Khuhawar and S.N. Lanjwani, J. Chem. Soc. Pak., 20, 204 (1998).

21. M.Y. Khuhawar, S.N. Lanjwani and T.M. Jahangir, Anal. Sci., 20, 193 (2004).

22. B.F. Liu, L.B. Liu and J.K. Cheng, J. Chromatogr. A, 834, 277 (1999).
23. V. Pacakova, P. Coufal and K. Stulik, J. Chromatogr. A, 834, 257 (1999).

24. M. Chiari, J. Chromatogr. A, 805, 1 (1998).

25. A.R. Timerbaev, Talanta, 52, 573 (2000).

26. M. Karkowiak, B. Fourest, S. Hubert and C. Moulin, J. Radiochem. Acta, 91, 505 (2003).

27. C. Vogt and G.L. Klunder, Frenenius. J. Anal. Chem., 370, 316 (2001).

28. A.R. Timerbaev and Q.A. Shpigun, Electrophoresis, 21, 4179 (2000).

29. G. Kepm, Biotechnol. Appl. Biochem., 27, 9 (1998).

30. L. Evans III and G.E. Collins, J. Chromatogr. A, 911, 127 (2001).

31. A.R. Timerbaev, O.P. Semenova, G.K. Bonn and J.S. Fritz, Anal. Chim. Acta, 296, 119 (1994).

32. B. Liu, L, Liu and J. Cheng, Anal. Chim. Acta, 358, 157 (1998).

33. M. Macka, P. Nesterenko, P. Andersson and P.R. Haddad, J. Chromatogr. A, 803, 279 (1998).

34. A. Mallah, S.Q. Memon, A.R. Solangi, M.Y. Khuhawar and M.I. Bhanger, Acta Chromatogr., 22, 405 (2010)

35. D. Chem and A.E. Martell, Inorg. Chem., 26, 1026 (1987).

36. K. Kanatoni, I. Muraze and A.E. Martell, J. Inorg. Nucl. Chem., 38, 1465 (1976).

37. A. Pasini, N. Gullotti and E. Casarotti, J. Inorg. Nucl. Chem., 34, 3821 (1972)

38. W.H. Mills and T.H.H. Quibell, J. Chem. Soc., 839 (1935).

39. M.A. Mirza, A.J. Kandhro, M.Y. Khuhawar and R. Arain, J. Sep Sci., 32, 3169 (2009). 